Wrocławskie Studia Wschodnie

23 (2019)

Wydawnictwo Uniwersytetu Wrocławskiego

DOI: $10.19195 / 1429-4168.23 .4$

StanisłaW Ciesielski

ORCID: 0000-0002-4293-0113

Uniwersytet Wrocławski

\title{
Stalin przeciwko Pokrowskiemu. Z dziejów stalinowskiej „polityki historycznej”
}

Michaił Nikołajewicz Pokrowski to symbol marksistowskiej historiografii w ZSRR w latach dwudziestych i w pierwszej połowie lat trzydziestych XX wieku. Jego poglądy na historię, jej metodologię, funkcje i zadania, jego koncepcje procesu dziejowego i tworzone przez niego obrazy poszczególnych zjawisk i wydarzeń budziły i budzą różnorakie oceny. Kontrowersyjny jest także jego dorobek w sferze oświaty i organizacji nauki oraz jego stosunek do poszczególnych historyków i całych grup uczonych ${ }^{1}$. Nie jest intencją autora przedstawienie poglądów Pokrowskiego i jego uczniów, orzekanie o słuszności lub błędności tych poglądów, a tym bardziej o trafności ich naukowej krytyki. Celem tego artykułu jest zaprezentowanie stosunku Stalina do Pokrowskiego, do jego poglądów na przeszłość i na historię jako naukę, a w konsekwencji próba wyjaśnienia sensu kampanii zainicjowanej przez Stalina przeciwko Pokrowskiemu i jego „szkole”.

Analizy recepcji prac Pokrowskiego dowodzą, że w zasadzie przez cały czas jego aktywności pojawiały się ze strony autorów o różnych orientacjach ideologicznych i metodologicznych głosy krytyki, a nawet negacji jego poglą-

${ }^{1}$ W obliczu mnogości opracowań dotyczących Pokrowskiego i jego dorobku wskazać tu można jedynie kilka: J.A. Łuckij, Razwitije istoriczeskoj koncepcyi M.N. Pokrowskogo, [w:] Istorija $i$ i istoriki. Istoriografija istorii SSSR. Sbornik statiej, red. M.N. Nieczkina, Moskwa 1965, s. 334-370; O.D. Sokołow, M.N. Pokrowskij i sowietskaja istoriczeskaja nauka, Moskwa 1970; H. Asher, The rise, fall, and resurrection of M.N. Pokrovsky, „The Russian Review” 1972, nr 1, s. 49-63; A.A. Goworkow, M.N. Pokrowskij o priedmietie istoriczeskoj nauki, Tomsk 1976; G.M. Enteen, The Soviet Scholar Bureaucrat: M.N. Pokrovskii and the Society of Marxist Historians, Pensylvania 1978; A.A. Czernobajew, „Profiessor s pikoj” ili tri żyzni istorika M.N. Pokrowskogo, Moskwa 1992; G.D. Aleksiejewa, Istorija, Idieołogija. Politika. (20-30-je gg), [w:] Istoriczeskaja nauka Rossii w XX wiekie, red. G.D. Aleksiejewa, Moskwa 1997, s. 79-166.

Wrocławskie Studia Wschodnie 23, 2019

(C) for this edition by CNS 
dów. Od drugiej połowy lat dwudziestych prym w tej krytyce wiedli młodzi adepci metodologii marksistowskiej, wywodzący się głównie z Instytutu Czerwonej Profesury. Wtedy właśnie pojawiły się — przede wszystkim w odniesieniu do jego koncepcji kapitału handlowego i jego roli w dziejach Rosji — zarzuty głoszenia koncepcji sprzecznych z poglądami Marksa i Lenina, scholastycznych, niedialektycznych ${ }^{2}$. Ataki na Pokrowskiego, a w jeszcze większym stopniu na niektórych jego uczniów i współpracowników, były tak silne, że uczony 5 lutego 1931 roku skierował w tej sprawie list do sekretarzy $\mathrm{KC}$ WKP(b $)^{3}$. Nic nie wiadomo o odpowiedzi na ów list czy o konsekwencjach wyciągniętych wobec przeciwników Pokrowskiego. Jednakże mimo bardzo ostrej krytyki pod jego adresem i kwestionowania jego kierownictwa w Akademii Komunistycznej (prawdopodobnie inspirowanego przez Łazara Kaganowicza) Stalin nie cofnął mu swego poparcia i jego pozycja w Akademii i w innych instytucjach i organizacjach nie została zachwiana 4 .

Stosunek Stalina do Pokrowskiego w tym okresie można określić jako pragmatyczny. Nawet jeśli miał jakieś zastrzeżenia do poglądów uczonego, to popierał i sankcjonował jego karierę w organizacjach i instytucjach różnego rodzaju, przyczyniając się w ten sposób do zbudowania jego autorytetu i znaczenia. Stalin pozwolił sobie jednak wyrazić przekonanie, że Pokrowski należał do „starych przywódców i literatów”, których czas mijał wraz z rozwojem partii i którzy odchodzili na drugi plan w ramach procesu odnawiania $\mathrm{kadr}^{5}$. Nie łączyło się to z formułowaniem jakichś zarzutów czy wątpliwości. Pokrowski pełnił wysokie funkcje w strukturach administracyjnych, naukowych i partyjnych, a w 1930 roku zajął najwyższe stanowisko polityczne w swojej karierze, wchodząc do Prezydium Centralnej Komisji Kontroli WKP(b). Stalin miał zresztą okazję bezpośrednio odnieść się do historycznych poglądów Pokrowskiego. Odpowiadając na pytania słuchaczy Instytutu Czerwonej Profesury, jego koncepcję powstania rosyjskiego samowładztwa uznał za ,zasadniczo prawidłową, chociaż niepozbawioną skrajności i przegięć w kierunku uproszczonego, ekonomicznego wyjaśnienia procesu

2 J.A. Łuckij, op. cit., s. 362-365; J. Barber, Soviet Historians in Crisis 1928-1932, London-Basingstoke 1981, s. 60-67, 122-125; O.D. Sokołow, op. cit., s. 9-18; W.J. Sokołow, Istorija i politika ( $K$ woprosu o sodierżanii i charaktierie diskussij sowietskich istorikow 1920ch-naczała 1930-ch gg.), Tomsk 1990, passim; A.N. Artizow, Kritika M.N. Pokrowskogo i jego szkoły (K istorii woprosa), „Istorija SSSR” 1991, nr 1, s. 103-105.

3 Akadiemik P.O. Gorin. Dokumienty i matieriaty, red. N.W. Tokariew, Minsk 2011, s. 8385.

4 J. Barber, op. cit., s. 124-125.

5 I.W. Stalin, Soczinienija, t. 7, Moskwa 1952, s. 43.

Wrocławskie Studia Wschodnie 23, 2019

(C) for this edition by CNS 
tworzenia samowładztwa" odnosiła się do polemiki Pokrowskiego z Trockim. Wydaje się, że zaangażowanie Pokrowskiego w zwalczanie poglądów Trockiego w ogóle mogło być ważnym czynnikiem określającym stosunek Stalina do uczonego.

Jemielan Jarosławski, konkurent Pokrowskiego do miana głównego marksistowskiego historyka w ZSRR, w liście do Stalina z 22 stycznia 1936 roku przypominał adresatowi, jakoby ten już latem czy też wiosną 1930 roku w trakcie rozmowy z nim twierdził, że Pokrowski nie był marksistą i popełniał wiele błędów, które należało poddać krytyce ${ }^{7}$. Nawet jeżeli było tak, jak wspominał Jarosławski, to z opinii tej nic wówczas nie wyniknęło. Kilkanaście miesięcy później w opałach znalazł się zaś sam Jarosławski za sprawą krytycznych uwag pod jego adresem wyrażonych przez Stalina w liście do redakcji czasopisma „Proletarskaja riewolucyja"8.

Jako krytykę, ale jeszcze nie imienną, stanowiska Pokrowskiego, przede wszystkim w sprawie nauczania historii, można potraktować odwrót od polityki oświatowej realizowanej w latach dwudziestych. W związku z tym resort oświaty został zobowiązany do opracowania nowych programów nauczania i podręczników9. W toku prac działającej przy Ludowym Komisariacie Oświaty komisji do spraw podręczników 17 lutego 1933 roku postanowiono skierować do Kolegium Ludowego Komisariatu Oświaty wniosek o umieszczenie w spisie podręczników do szkoły średniej książki Pokrowskiego Historia rosyjska $w$ najzwięźlejszym zarysie. Propozycja ta została wprawdzie zatwierdzona przez Kolegium, ale 6 marca 1933 roku na forum komisji ponownie doszło do dyskusji na temat tej publikacji. Ujawnione wówczas różnice zdań musiały być poważne, skoro postanowiono powiadomić o tym kierownika Wydziału Kultury i Propagandy KC WKP(b) Aleksieja Stieckiego ${ }^{10}$. Niewykluczone, że pod wpływem jego uwag komisja podręcznikowa 2 kwietnia 1933 roku powróciła do kwestii wykorzystania pracy Pokrowskiego jako podręcznika szkolnego. Stosunek do tej książki zmienił

${ }^{6}$ Cyt. za: M. Nieczkina, Wopros o Pokrowskom w postanowlenijach partii i prawitielstwa 1934-1938 gg. o priepodawanii istorii $i$ istoriczeskoj naukie (K istocznikowiedczeskoj storonie tiemy), „Istoriczeskije Zapiski” 118, 1990, s. 243; jeśli nie podano inaczej, przeł. S.C. W „Dziełach” Stalina brakuje tego fragmentu - I.W. Stalin, Soczinienija, t. 9, Moskwa 1948, s. 178 .

${ }^{7}$ I.W. Stalin. Istoriczeskaja idieołogija w SSSR w 1920-1950-je gody. Pieriepiska s istorikami, stati i zamietki po istorii, stienogrammy wystuplenij. Sbornik dokumientow i matieriałow, red. M.W. Zielenow, t. 1, Sankt-Pietierburg 2006, s. 215.

${ }^{8}$ S. Ciesielski, Poczatki stalinowskiego zwrotu wobec historii (1930-1931), ,Wrocławskie Studia Wschodnie" 21, 2017, s. 101-108.

${ }^{9}$ Szerzej zob. S. Ciesielski, Rewolucja Stalina, Łomianki 2017, s. 348-349.

10 A.M. Dubrowskij, Istorik $i$ wtast'. Istoriczeskaja nauka w SSSR i koncepcyia istorii fieodalnoj Rossii w kontiekstie politiki i idieołogii (1930-1950-je gg), Briansk 2005, s. 176.

Wrocławskie Studia Wschodnie 23, 2019

(C) for this edition by CNS 
się w znaczący sposób. O ile 17 lutego zaakceptowano ją bez zastrzeżeń, teraz za konieczne uznano wprowadzenie do niej zmian wynikających z ogłoszenia przez Pokrowskiego artykułu $O$ rosyjskim feudalizmie $i$ charakterze absolutyzmu w Rosji, częściowo rewidującego wcześniejsze poglądy autora. Jednocześnie zaś stwierdzono, że nieodzowne będzie stworzenie zupełnie nowego podręcznika do historii Rosji i ZSRR, co w perspektywie oznaczało porzucenie korzystania z niezwykle popularnej książki Pokrowskiego. Powołany został zespół autorski pod przewodnictwem Nikołaja Wanaga ${ }^{11}$, w większości złożony z uczniów Pokrowskiego, a zatem trudno było mówić o negatywnym stosunku do jego ,szkoły”.

Problem nauczania historii 5 marca 1934 roku trafił pod obrady Biura Politycznego KC WKP(b). Protokół posiedzenia odnotował tylko, że za punkt ten odpowiedzialni byli Stalin i szef resortu oświaty Andriej Bubnow ${ }^{12}$. Zasadnicze elementy wypowiedzi Stalina znane są tylko z o kilka dni późniejszych wystąpień Bubnowa i Stieckiego. Ten pierwszy już 8 marca na zwołanej przez siebie naradzie historyków przedstawił zdecydowanie krytyczną ocenę sytuacji w zakresie podręczników szkolnych i programów nauczania historii. Szczególne znaczenie miała teza, że tradycyjną narrację zastąpiono ujęciami socjologicznymi, przedstawiając schematy formacji społeczno-ekonomicznych oderwane od konkretnych wydarzeń i postaci. Był to motyw, który będzie systematycznie powtarzany $\mathrm{w}$ związku z poruszaną problematyką, zarówno w czasie, gdy publicznie nazwisko Pokrowskiego nie było wiązane z krytykowaną sytuacją, jak i później, w fazie jawnej kampanii przeciwko uczonemu i jego „szkole”. Referując stanowisko Stalina, Bubnow na określenie nowego sposobu ujmowania przeszłości posługiwał się terminem pragmaticzeskaja istorija ${ }^{13}$. Stiecki stanowisko Stalina zaprezentował 13 marca 1934 roku na posiedzeniu Prezydium Akademii Komunistycznej. Według tego przekazu Stalin uznał, że ani sposób nauczania historii, ani podręczniki do tego przedmiotu nie odpowiadały oczekiwaniom i potrzebom. Historię zastąpiła socjologia, podręczniki wypełniły schematyczne ujęcia okresów historycznych, ogólne charakterystyki systemów gospodarczych, całkowicie brakowało zaś obrazu rzeczywiście zachodzących wydarzeń, nie przedstawiano wybitnych postaci historycznych ${ }^{14}$. Stiecki na określenie nowego wzorca

11 Ibidem, s. 177; A.N. Artizow, Nikołaj Nikołajewicz Wanag (1899-1937 gg.), „Otieczestwiennaja Istorija” 1992, nr 6, s. 103.

12 Politbiuro CK RKP(b)-WKP(b). Powiestki dnia zasiedanij 1919-1952. Katałog, red. G.M. Adibiekow, K.M. Anderson, L.A. Rogowaja, t. 2, Moskwa 2001, s. 505.

13 „Nużen bolszewistskij Iłowajskij”. Iz stienogrammy sowieszczanija narkoma proswieszczenija RSFSR A.S. Bubnowa s istorikami o stabilnom uczebnikie, red. S.J. Zaczejko, T.J. Krasowickaja, http://www.alexanderyakovlev.org/almanah/inside/almanah-doc/1022578 (dostęp: 17.03.2017).

14 A.M. Dubrowskij, op. cit., s. 182-184.

Wrocławskie Studia Wschodnie 23, 2019

(C) for this edition by CNS 
użył — bez wątpienia za Stalinem - terminu grażdanskaja istorija, który był następnie konsekwentnie używany w oficjalnych dokumentach partyjnych i państwowych. Termin ten nie ma dobrego polskiego odpowiednika, a pojmować go należy jako narrację polegającą na chronologicznym opisie wydarzeń, skupioną przede wszystkim na zjawiskach politycznych i prezentującą aktywność wybitnych jednostek.

Nie ulega wątpliwości, że 5 marca 1934 roku Stalin dał sygnał do przebudowy podejścia do historii jako nauki i przedmiotu kształcenia. Nie było to wszakże jego pierwsze wystąpienie o takim charakterze. Już krytyka felietonów poetyckich Diemjana Biednego oraz list do redakcji „Proletarskoj riewolucyi" dowodziły, iż Stalin wcześniej przewartościowywał niektóre elementy dotychczasowej „polityki historycznej”15. Z przekazów Bubnowa i Stieckiego wynikało, że idea nowego spojrzenia na przeszłość była dość wyraźna - chodziło o powrót do tradycyjnego przedstawiania procesu historycznego, zwłaszcza jego sfery politycznej, z akcentem na „historię rosyjską”, jej czołowe postacie i kluczowe dla niej zjawiska budowy samowładztwa, „zbierania ziem ruskich” itp. Zwraca tu uwagę wyraźna tendencja do akcentowania w dziejach roli jednostki, zwłaszcza przywódczej. Stalin osobiście był zainteresowany porzuceniem charakterystycznego dla Pokrowskiego traktowania takich postaci jako figurantów, za którymi kryły się siły sprawcze o charakterze klasowym.

Ze znanych przekazów można wnosić, że 5 marca 1934 roku nazwisko Pokrowskiego nie padło. Inaczej było jednak już na kolejnym posiedzeniu Biura Politycznego, 20 marca 1934 roku, w którym udział wzięło kilku historyków zaproszonych według trudnego do ustalenia klucza ${ }^{16}$. Punktem wyjścia był raport przygotowany przez Aleksieja Stieckiego, Andrieja Bubnowa i Andrieja Żdanowa ${ }^{17}$. Kluczowe znaczenie miało jednak wystapienie Stalina, którego treść odnotowali w swoich wspomnieniach uczestnicy zebrania ${ }^{18}$. Stalin miał kilkakrotnie powtórzyć, że istniejące podręczniki nie były nic warte, posługiwały się bowiem ogólnikowymi pojęciami i były pozbawione konkretnych treści historycznych, faktografii, informacji o ważnych postaciach. Jego zdaniem „historia powinna być historią”, potrzebne były podręczniki do historii starożytnej, średniowiecznej, nowożytnej, historii ZSRR, historii narodów kolonialnych i zależnych. Znamienny był sprzeciw Stalina wobec propozycji Bubnowa, by zamiast historii ZSRR powstał podręcznik historii narodów ZSRR. Stalin miał wówczas rzucić następującą uwagę:

15 Szerzej zob. S. Ciesielski, Poczatki stalinowskiego zwrotu..., s. 89-108.

16 A.M. Dubrowskij, op. cit., s. 190.

17 D.L. Brandenberger, A.M. Dubrovsky, "The people need a tsar": The emergence of national bolshevism as stalinist ideology 1931-1941, „Europe-Asia Studies” 1998, nr 5, s. 875.

18 A.M. Dubrowskij, op. cit., s. 191.

Wrocławskie Studia Wschodnie 23, 2019

(C) for this edition by CNS 
„naród rosyjski w przeszłości zbierał inne narody, do tegoż zbierania przystąpił także obecnie". W takim kontekście sekretarz generalny skrytykował koncepcje Pokrowskiego, określając je jako niemarksistowskie i przypisując im negatywny wpływ na ujmowanie historii i jej nauczanie w ZSRR ${ }^{19}$. Ta właśnie ocena zainicjowała krytykę Pokrowskiego i jego „szkoły”, aczkolwiek początkowo inicjatywa ta była znana w stosunkowo wąskim gronie, publicznie bowiem nazwisko uczonego nie było łączone $\mathrm{z}$ dokonywanymi zmianami.

Dlaczego Stalin zdecydował się zaatakować poglądy zmarłego dwa lata wcześniej Pokrowskiego, dotąd publicznie uznawanego za najwybitniejszego historyka marksistowskiego, pełniącego najbardziej odpowiedzialne funkcje w strukturach instytucjonalnych nauki i gorliwie realizującego linię partii bolszewickiej? I czy wytyczenie nowych zasad ,polityki historycznej” oraz traktowania historii jako nauki i przedmiotu nauczania, nawet jeśli prowadziło do porzucenia koncepcji promowanych przez Pokrowskiego, wymagało potępienia uczonego, zwłaszcza w takich formach, jak miało to miejsce później?

Przejście do nowej koncepcji historii ojczystej w kształcie nadawanym jej teraz przez Stalina napotykało istniejącą wizję, w dużej mierze wyznaczoną przez Pokrowskiego i jego współpracowników. Niezbędna okazała się dyskredytacja tej wizji, a instrumentem tej dyskredytacji było ogłoszenie, że poglądy Pokrowskiego i jego uczniów były antymarksistowskie czy wulgaryzatorskie $^{20}$. Jeżeli kierownictwo partii i państwa dokonywało istotnego zwrotu w jakiejkolwiek sferze polityki, to pojawiała się konieczność uzasadnienia takiego posunięcia. Jeżeli dotychczasowa polityka została uznana za błędną, to odpowiedzialność za błędy nie mogła obarczać kierownictwa - ono w imię stabilności systemu musiało bowiem zachować atrybut nieomylności. Skoro zatem realizowana miała być nowa „polityka historyczna” i społeczeństwo miało jej doświadczyć poprzez system propagandowy, oświatowy i kulturalny, to niezbędne było uzasadnienie odrzucenia dotychczasowej linii, a więc znalezienie „kozła ofiarnego”, któremu można by przypisać odpowiedzialność za błędy. Sądzić można, że do pewnego momentu Stalin żywił nadzieję, że ów „kozioł ofiarny” sam podda krytyce dotychczasowe stanowisko i spełni oczekiwania kierownictwa. Taki mógł być sens powierzenia zespołowi pod kierownictwem Wanaga napisania nowego podręcznika szkolnego do historii ZSRR ${ }^{21}$.

${ }^{19}$ Dniewnik istorika S, A. Piontowskogo (1927-1934), red. A.L. Litwin, Kazań 2009, s. 506507.

${ }^{20}$ W.W. Tichonow, Istoriki, idieołogija, włast'w Rossii XX wieka. Oczerki, Moskwa 2014, s. 82 .

21 Politbiuro..., t. 2, s. 317-318.

Wrocławskie Studia Wschodnie 23, 2019

(C) for this edition by $\mathrm{CNS}$ 
Decyzje Biura Politycznego w połowie maja uzyskały formę wspólnych uchwał KC WKP(b) i Rady Komisarzy Ludowych ZSRR. Stalin osobiście zredagował postanowienie o nauczaniu historii ${ }^{22}$, zatem można je uznać za dobrze wyrażające stanowisko sekretarza generalnego. Charakteryzując ówczesny stan nauczania historii, dokument wskazywał, że zamiast „w żywej, interesującej formie” przedstawiać najważniejsze zjawiska i fakty „w ich chronologicznym następstwie", w powiązaniu z charakterystyką postaci historycznych, podawano ,abstrakcyjne określenia formacji społeczno-gospodarczych”, zastępując w ten sposób wykład historii „schematami socjologicznymi”. W części drugiej stwierdzono zaś, że

Decydującym warunkiem trwałego przyswojenia przez ucznia kursu historii jest zachowanie historyczno-chronologicznego następstwa w przedstawianiu wydarzeń historycznych z obowiązkowym utrwaleniem w pamięci ucznia ważnych zjawisk historycznych, działaczy historycznych, chronologicznych dat. Tylko taki kurs historii może zapewnić niezbędną dla uczącego się dostępność, obrazowość i konkretność materiału historycznego, a jedynie na podstawie tego możliwe jest właściwe rozpatrywanie i prawidłowe uogólnienie historycznych wydarzeń, prowadzące ucznia do marksistowskiego rozumienia historii ${ }^{23}$.

Jakkolwiek oceny te formalnie odnosiły się do edukacji szkolnej, ich rzeczywiste znaczenie było dużo większe. W tym przeznaczonym do upowszechnienia dokumencie Stalin nie zdecydował się bowiem na wskazanie Pokrowskiego i jego „szkoły” jako nosicieli skrytykowanych tendencji, natomiast wprowadzone pojęcia i zwroty zyskały trwałe miejsce w języku późniejszej kampanii przeciwko uczonemu.

Latem 1934 roku Stalin zapoznał się z konspektami projektowanych podręczników do historii $Z_{\text {SRR }}{ }^{24}$ i do historii nowożytnej ${ }^{25}$, a następnie podzielił się swoimi spostrzeżeniami z Siergiejem Kirowem i Andriejem Żdanowem. Uwagi z powodu konspektu podręcznika do historii ZSRR (Zamieczanija po powodu konspiekta uczebnika po istorii SSSR) oraz Uwagi o konspekcie podręcznika historii nowożytnej (Zamieczanija o konspiektie uczebnika nowoj istorii) podpisane zostały przez całą trójkę ${ }^{26}$, a w wyniku zatwierdzenia ich przez Biuro Polityczne 14 sierpnia 1934 roku $^{27}$ formalnie stały się dokumentem partyjnym. Uwagi były wielokrotnie publikowane, analizowane i komen-

22 Poprawki Stalina do pierwotnego projektu postanowienia zob. I.W. Stalin. Istoriczeskaja idieotogija..., s. 190-192.

$23 \mathrm{http} / /$ www.libussr.ru/doc_ussr/ussr_3989.htm (dostęp: 17.08.2016).

24 Tekst konspektu zob. Käk Stalin kritikowat i riedaktirowat konspekty szkolnych uczebnikow po istorii (1934-1936 gody), oprac. M.W. Zielenow, „Woprosy Istorii” 2004, nr 6, s. $11-15$.

25 Tekst konspektu zob. ibidem, s. 16-17.

${ }^{26}$ I.W. Stalin. Istoriczeskaja idieołogija ..., s. 203-206.

27 Ibidem, s. 207.

Wrocławskie Studia Wschodnie 23, 2019

(C) for this edition by CNS 
towane ${ }^{28}$, nie ma zatem potrzeby referowania tutaj ich treści. Ujawniały one kolejne elementy podejścia Stalina do przeszłości, historii jako nauki i sposobów wykorzystywania historii w działalności ideowo-politycznej. W Uwagach nie ma bezpośrednich odniesień do koncepcji Pokrowskiego, jednakże wiele spostrzeżeń Stalina, zwłaszcza odnośnie do historii Rosji, stanowiło przejawy podejścia alternatywnego w stosunku do prac tego badacza. Stalin sygnalizował konieczność uwzględniania pewnych elementów ciągłości historii Rosji i ZSRR, dostrzegania elementów postępowych i odpowiedniego ich naświetlania, oceniania polityki rosyjskiej z perspektywy czasu i kontekstu jej realizacji. Poglądy Stalina w tym zakresie staną się o wiele czytelniejsze przy analizowaniu Uwag łącznie z listem do członków Biura Politycznego kwestionującym zasadność opublikowania artykułu Friedricha Engelsa ${ }^{29}$. Stalin nie zdecydował się wówczas na ogłoszenie obu tych dokumentów. Swego rodzaju substytutem ich publikacji stał się artykuł Anny Pankratowej $O$ bolszewickie nauczanie historii, wydrukowany na początku 1935 roku w czasopiśmie „Bor’ba kłassow" ${ }^{30}$. Ta marginalnie tylko odnotowywana przez historyków publikacja była bez wątpienia przygotowana „na zamówienie” władz politycznych, a autorce udostępniono materiały $\mathrm{z}$ posiedzeń Biura Politycznego KC WKP(b) w marcu 1934 roku oraz Uwagi Stalina, Kirowa i Żdanowa.

Pankratowa powtarzała zarzuty Stalina wobec istniejących podręczników do historii: schematyzm, socjologizm, brak konkretnego materiału faktograficznego. Nowością była informacja o dokonanej przez Stalina krytyce konspektów przygotowywanych dopiero podręczników. Z uwagi na rozpatrywaną tu problematykę istotne było odniesienie się autorki do dorobku Pokrowskiego. Pozytywnie oceniła ona jego elementy burzące „burżuazyjne i drobnomieszczańskie schematy rosyjskich historyków". Natomiast we własnych koncepcjach uczonego widziała „,szereg takich istotnych błędów, które nie mogły uczynić jego schematu możliwym do przyjęcia”, dodając, że wprawdzie Pokrowski sam poddał „swój schemat o kapitale handlowym jako trzonie historii rosyjskiej dość poważnej krytyce, ale przezwyciężyć tego schematu do końca jednak nie mógł"31. Kompozycja artykułu i sposób łączenia poszczególnych problemów tworzyły wrażenie, że przynajmniej znaczna część krytycznych opinii Stalina odnosiła się właśnie do poglądów

28 Zob. np. D.L. Brandenberger, A.M. Dubrovsky, op. cit., s. 238; M. Perrie, The Cult of Ivan the Terrible in Stalin's Russia, Basingstoke 2001, s. 26.

${ }^{29}$ I.W. Stalin — „O statje Engelsa »Wniesznaja politika russkogo carizma«”- i idieołogiczeskaja podgotowka k mirowoj wojnie, red. M.W. Zielenow, „Woprosy istorii” 2002, nr 7, s. $14-18$.

30 A. Pankratowa, Za bolszewistskoje priepodawanije istorii, „Bor’ba kłassow” 1935, nr 1-2, s. 19 .

31 Ibidem, s. 29.

Wrocławskie Studia Wschodnie 23, 2019

(C) for this edition by CNS 
Pokrowskiego. Tekst był wykładem ówczesnego stanowiska stalinowskiego kierownictwa w kwestiach pojmowania historii jako nauki, przedstawiania historii Rosji i świata, celów edukacji historycznej, relacji między historią a teraźniejszością, a zwłaszcza aktualną polityką państwa radzieckiego. Był to, jak się wydaje, pierwszy publiczny wyraz krytyki koncepcji Pokrowskiego w duchu wystapienia Stalina z marca 1934 roku. To, że przedstawiła go Pankratowa, uczennica Pokrowskiego, która ledwie parę lat wcześniej publikowała o nim panegiryczne teksty ${ }^{32}$, nadawało mu szczególny sens, zapewne oczekiwany przez Stalina.

W sierpniu 1935 roku na biurko Stalina trafiła wcześniej wielokrotnie poprawiana makieta podręcznika pod redakcją Wanaga. Nie wiadomo jednak, czy dyktator się z nią zapoznał. W grudniu 1935 roku sporządzona została jej druzgocąca recenzja, której konkluzja wskazywała, że autorzy nie zrealizowali zaleceń i wskazań kierownictwa partii, nie przedstawili kultury narodów ZSRR, przede wszystkim kultury narodu rosyjskiego, a także nie pokazali postępowego znaczenia ,zbierania ziem ruskich” i stworzenia jądra państwa rosyjskiego, co stanowiło przejaw „lewackiego internacjonalizmu”33. Perspektywa opublikowania podręcznika została ostatecznie przekreślona, a sam Wanag został w 1937 roku aresztowany, skazany na śmierć i rozstrzelany. Lata 1934-1935 przyniosły faktyczne fiasko prób przygotowania przez przedstawicieli „,szkoły" Pokrowskiego podręczników odpowiadających oczekiwaniom Stalina. Doświadczenie to było zapewne przesłanką kampanii wymierzonej w ową „szkołę" i w dorobek jej lidera.

Do biura Stalina 21 stycznia 1936 roku trafił przesłany przez Żdanowa projekt dokumentu, który po poprawkach wniesionych przez sekretarza generalnego opatrzono datą 26 stycznia i sygnowano jako wspólne postanowienie KC WKP(b) i Rady Komisarzy Ludowych ${ }^{34}$. Postanowienie oficjalnie powoływało komisję pod przewodnictwem Żdanowa do spraw ,przeglądu i ulepszenia, a w nieodzownych przypadkach także do przerobienia napisanych już podręczników do historii”. Przyznano jej prawo do tworzenia grup do przeglądu poszczególnych istniejących już podręczników oraz do rozpisania konkursu na nowe ${ }^{35}$. Komisja podjęła działalność, nim formalnie została utworzona - na pierwszym posiedzeniu spotkała się bowiem już 17 stycznia i wysłuchała raportów z prac zespołów zajmujących się poszczególnymi grupami podręczników, między innymi do historii ZSRR i historii powszechnej.

32 A. Pankratowa, M.N. Pokrowskij — bolszewistskij istorik, „Bor'ba kłassow” 1932, nr 4, s. $20-35$.

33 A.M. Dubrowskij, op. cit., s. 261.

${ }^{34}$ Kak Stalin kritikowat..., s. 24.

${ }^{35}$ Postanowlenije CK WKP(b) i SNK Sojuza SSR, [w:] Na frontie istoriczeskoj nauki, Moskwa 1936, s. 5.

Wrocławskie Studia Wschodnie 23, 2019

(C) for this edition by CNS 
Prace tych zespołów musiały zatem trwać już wcześniej. Postanowiono, że 23 stycznia na łamach „Prawdy” i „Izwiestii” opublikowane zostaną materiały KC WKP(b) i rządu dotyczące podręczników. Artykuły komentujące te materiały mieli napisać Nikołaj Bucharin i Karl Radek ${ }^{36}$. Bucharin swój tekst przesłał Żdanowowi, a 22 stycznia także Stalinowi, przy okazji czołobitnie donosząc, że po przeczytaniu prac Pokrowskiego ,jeszcze raz przekonałem się, jak bardzo masz rację w obrocie steru na »froncie historycznym «"37.

Nie 23 stycznia, jak planowano, lecz 27 stycznia łamy „Prawdy” i „Izwiestii" wypełniły materiały dotyczące historii i jej nauczania. Wydrukowano wspomniane postanowienie powołujące komisję pod przewodnictwem Żdanowa, komunikat W Sownarkomie Sojuza SSR $i$ CK WKP(b), Uwagi Stalina, Kirowa i Żdanowa z sierpnia 1934 roku, a także artykuły wstępne.

Kluczowe znaczenie miał tekst $W$ Sownarkomie Sojuza SSR i CK WKP(b), który szczegółowo omawiał treść postanowienia rządu i KC WKP(b) z maja 1934 roku $^{38}$ oraz Uwagi Stalina, Kirowa i Żdanowa przedstawione teraz jako dokument zatwierdzony 14 sierpnia 1934 roku przez KC WKP(b) i Radę Komisarzy Ludowych. Konstatowano, że zawarte tam wskazówki i oceny nie znalazły zrozumienia wśród autorów nowych podręczników, którzy powtarzali skrytykowane już błędy ${ }^{39}$. W tym kontekście wskazano na Pokrowskiego i jego „szkołę” jako winowajców:

W sytuacji gdy autorzy wskazanych podręczników nadal obstają przy określeniach historycznych niejeden już raz ujawnionych przez partię i w oczywisty sposób niewytrzymujących krytyki i [przy] ustaleniach mających u podstaw znane błędy Pokrowskiego, Rada Komisarzy Ludowych i KC nie mogą nie uznać tego za dowód, że wśród pewnej części naszych historyków, szczególnie historyków ZSRR, zakorzeniły się antymarksistowskie, antyleninowskie, $\mathrm{w}$ istocie rzeczy likwidatorskie, antynaukowe poglądy na naukę historyczną [...] te szkodliwe tendencje i próby likwidacji historii jako nauki związane są w pierwszym rzędzie z rozprzestrzenieniem wśród niektórych naszych historyków błędnych poglądów historycznych, właściwych tak zwanej szkole historycznej Pokrowskiego. Rada Komisarzy Ludowych i KC wskazują, że zadanie przezwyciężenia tych szkodliwych poglądów stanowi niezbędną przesłankę zarówno powstania podręczników do historii, jak i rozwoju marksistowsko-leninowskiej nauki historycznej i wzrostu wykształcenia historycznego w ZSRR, mających bardzo ważne znaczenie dla sprawy naszego państwa, naszej partii i dla nauki dorastającego pokolenia ${ }^{40}$.

To ostatnie zdanie było otwartym wezwaniem do rozprawy ze „szkołą" Pokrowskiego. Tekst owego komunikatu stanowił później punkt wyjścia wielu publikacji ogłoszonych w toku kampanii przeciwko Pokrowskiemu, przy czym

\footnotetext{
${ }^{36}$ I.W. Stalin. Istoriczeskaja idieołogija..., s. 214-215.

37 Ibidem, s. 214.

38 W Sownarkomie Sojuza SSR i CK WKP(b), [w:] Na frontie..., s. 7-8.

39 Ibidem, s. 9-10.

40 Ibidem, s. 10.
}

Wrocławskie Studia Wschodnie 23, 2019

(C) for this edition by CNS 
wielokrotnie zawarte $\mathrm{w}$ nim sformułowania fałszywie przedstawiano jako fragmenty postanowienia KC WKP(b) i rządu.

Stalin otrzymał projekt tej publikacji od Żdanowa i wniósł do niego poprawki, które nie zmieniały jednak treści i wymowy zasadniczych twierdzeńn ${ }^{41}$. Oznaczało to, że w pełni akceptował zawarte tam oceny Pokrowskiego i jego „szkoły”. Milica Nieczkina nie miała wątpliwości, że pełną odpowiedzialność za atak na Pokrowskiego ponosił Stalin ${ }^{42}$. Przekonanie to podzielali później i inni badacze ${ }^{43}$. Odmienną opinię przedstawił Dawid Brandenberger, skłonny treść tego ataku przypisywać Bucharinowi i kwestionujący oddziaływanie Stalina na Żdanowa i Bucharina w okresie bezpośrednio poprzedzającym decyzje komisji Żdanowa. Brandenberger uznał, że Stalin jedynie zaakceptował projekt przygotowany przez Żdanowa. Ten ostatni zaś wykorzystał artykuł Bucharina przekazany mu przez autora do konsultacji ${ }^{44}$. Jeśli wierzyć pamięci Anny Łariny, to Stalin był inspiratorem wystąpienia Bucharina i rozmawiał z nim w tej sprawie telefonicznie, naciskając, by tekst miał „rozgromicielski" charakter 45 .

W artykule wstępnym „Prawdy” tezy zawarte w komunikacie zostały rozwinięte, a krytyka Pokrowskiego szczegółowiej uzasadniona. Przyznawano, że uczony prowadził walkę z burżuazyjnymi koncepcjami historii, którym przeciwstawił rozwój stosunków ekonomicznych jako podstawowy czynnik procesu dziejowego. Jednakże redukując materializm dialektyczny do ekonomizmu, nie zdołał przedstawić rzeczywistej historii walki klasowej i roli państwa w tej walce, zastępował ,żywą historię" „martwym schematem”, w którym główną rolę odgrywała fałszywie tłumacząca istotę caratu teoria kapitału handlowego. Stworzył koncepcję antyleninowską i przez to antynaukową. Konkluzja brzmiała:

Walka z antyleninowskimi tradycjami szkoły Pokrowskiego i co do metody, i co do konkretnego obrazu rosyjskiej historii, przezwyciężenie tradycji szkoły Pokrowskiego jest warunkiem stworzenia marksistowsko-leninowskiej historii $\mathrm{ZSRR}^{46}$.

Niezwykle ważna, odzwierciedlająca stalinowską orientację na wartości determinujące spojrzenie na historię, była uwaga stwierdzająca, że masy ludowe

${ }^{41}$ I.W. Stalin. Istoriczeskaja idieołogija ..., s. 212.

${ }^{42}$ M.W. Nieczkina, Wopros..., s. 239.

43 A.A. Czernobajew, op. cit., s. 202-204; I.W. Stalin. Istoriczeskaja idieołogija..., s. 185.

44 D. Brandenberger, Politics projected into the past: What precipitated the 1936 campaign against M.N. Pokrovsky?, [w:] Reinterpreting Revolutionary Russia: Essays in Honour of James D. White, red. I.D. Thatcher, London 2006, s. 206-207; D. Brandenberger, Who killed Pokrovskii? (the second time): The prelude to the denunciation of the father of Soviet marxist historiography, January 1936, „Revolutionary Russia” 1998, nr 1, s. 69.

45 A.M. Łarina, Niezabywajemoje, Moskwa 1989, s. 32.

46 Priepodawanije istorii w naszej szkole, [w:] Na frontie..., s. 26.

Wrocławskie Studia Wschodnie 23, 2019

(C) for this edition by CNS 
muszą otrzymać nie martwy schemat powstających i rozwijających się formacji społeczno-ekonomicznych, lecz konkretny obraz walki klas z charakterystyką ich przywódców, z konkretną charakterystyką stosunków klasowych w tej walce, tylko bowiem w ten sposób historia nauczy je tego, co stanowi jej zadanie jako nauki o polityce, tj. o walce o władzę i jej utrzymanie ${ }^{47}$.

Zainicjowana styczniowymi publikacjami kampania przeciwko Pokrowskiemu i jego „szkole” szybko nabrała znacznej skali i przybrała formę zarówno różnorakich publikacji w prasie codziennej i specjalistycznej, jak i wypowiedzi na bardziej czy mniej zamkniętych posiedzeniach rozmaitych gremiów. Brak miejsca nie pozwala na przeprowadzenie tu analizy wszystkich tych enuncjacji. Zresztą jądro ogromnej większości z nich stanowił zestaw stale powtarzanych oskarżeń biorących swój początek w materiałach opublikowanych na początku 1936 roku z inspiracji i pod pełną kontrolą Stalina. Poszczególni uczestnicy kampanii rozwijali je, ilustrowali przykładami dobieranymi zazwyczaj jednostronnie pod z góry przyjęte tezy, a uczeni nadawali im znamiona naukowej analizy. Dała się przy tym zaobserwować tendencja do zaostrzania języka tych wypowiedzi, a po lutowo-marcowym plenum KC WKP(b) w 1937 roku zaczęły je wypełniać kalumnie rzucane na krytykowanych historyków w duchu dominujących tam ocen i sformułowań. Coraz ważniejszy kontekst kampanii stanowiły represje wobec środowiska historyków, a wraz z tym narastające obawy wielu z nich o osobiste bezpieczeństwo. Jakkolwiek w poszczególnych enuncjacjach zasadnicze oskarżenia pojawiały się w różnych konfiguracjach i ze zróżnicowaną intensywnością, można pokusić się o stworzenie ich katalogu stanowiącego swoiste odzwierciedlenie stalinowskiego stosunku do Pokrowskiego i przypisywanych mu — gdyż nie zawsze przez niego formułowanych — poglądów.

Pojawiały się opinie, że Pokrowski opierał się na „olbrzymim materiale historycznym”, „był historykiem o olbrzymiej wiedzy i błyskotliwym talencie pisarskim,"48, a Bucharin pisał o nim nawet jako o ,wielkim uczonym - marksiście-historyku"49, ale miało to miejsce na początku kampanii i słabo korespondowało z innymi twierdzeniami tych samych autorów. Zazwyczaj odnotowywano zasługi Pokrowskiego w zwalczaniu „burżuazyjnych” i „drobnomieszczańskich" koncepcji historycznych ${ }^{50}$, choć pojawiały się także twierdzenia

47 Ibidem, s. 24.

${ }^{48}$ K. Radek, Niedostatki istoriczeskogo fronta i oszybki szkoły Pokrowskogo, „Bor’ba kłassow" 1936, nr 3, s. 24-25, 35.

49 N.I. Bucharin, Nużna li nam marksistskaja istoriczeskaja nauka? (O niekotorych suszczestwienno ważnych, no nie sostojatielnych wzgliadach t. M.N. Pokrowskogo), „Bor'ba kłassow" 1936, nr 2, s. 12-13.

${ }^{50} \mathrm{P}$. Gorin, O niekotorych likwidatorskich wzgliadach na istoriczeskuju nauku, „Bolszewik" 1936, nr 7, przedruk w: Akadiemik P.O. Gorin..., s. 283; P. Drozdow, Rieszenije partii i prawitielstwa ob uczebnikach po istorii $i$ zadaczi sowietskich istorikow, „Istorik-marksist” 1936, nr 1 (53), s. 13. N.I. Bucharin, op. cit., s. 12-13; Istorik i wriemia. 20-50-je gody XX wieka. A.M. Pankratowa, red. J.S. Kukuszkin, Moskwa 2000, s. 206-207.

Wrocławskie Studia Wschodnie 23, 2019

(C) for this edition by CNS 
wskazujące na wpływ „burżuazyjnego schematu historycznego" na stanowisko Pokrowskiego w wielu kwestiach ${ }^{51}$. „Nawróceni” na marksizm przedstawiciele „starej szkoły” chętnie podkreślali, że Pokrowski nie zdołał przezwyciężyć ograniczoności historyków burżuazyjnych, czy wręcz pozostawał „w niewoli” ich koncepcji ${ }^{52}$. W końcu w ogóle zakwestionowano znaczenie prowadzonej przez Pokrowskiego krytyki historiografii burżuazyjnej, stwierdzając, że nie opanowawszy marksizmu, nie mógł konsekwentnie występować przeciwko niej ${ }^{53}$.

Powszechne było określanie poglądów Pokrowskiego jako antymarksistowskich i antyleninowskich. Wyszukiwano rzeczywiste lub wyimaginowane niezgodności wypowiedzi uczonego z odpowiednio zinterpretowanymi poglądami klasyków, zarówno odnoszącymi się do konkretnych problemów przeszłości, jak i kwestii teoretycznych. Tego rodzaju metodą posługiwali się przede wszystkim autorzy zaliczani i sami uważający się za marksistów, w tym profesjonalni historycy, aczkolwiek również niektórzy przedstawiciele „starej szkoły” nie stronili od wspierania się Leninem i Stalinem. W argumentacji na rzecz owej kwalifikacji poglądów Pokrowskiego jako antymarksistowskich i antyleninowskich szczególnie ważne miejsce miało wskazanie na materializm ekonomiczny jako przesłankę koncepcji uczonego. Niezdolność do wyzwolenia się ze schematów materializmu ekonomicznego, niezrozumienie i nieprzyswojenie sobie marksistowskiej dialektyki miało prowadzić czy to do wulgaryzacji marksizmu, czy wręcz do jego odrzucenia ${ }^{54}$. Niektórzy autorzy zarzucali Pokrowskiemu jednocześnie materializm ekonomiczny i idealizm, co sugeruje, że nie liczyła się logiczna spójność zarzutów, lecz ich ciężar gatunkowy zawarty w etykietach ${ }^{55}$.

Jednym z najcięższych zarzutów wobec Pokrowskiego było przypisanie mu hołdowania teoriom subiektywizmu poznawczego, uznawania historii za politykę rzutowaną w przeszłość, odrzucenia obiektywnego charakteru historii jako nauki, a w konsekwencji uznanie, że negował historię jako naukę i reprezentował likwidatorskie do niej podejście ${ }^{56}$.

${ }^{51}$ M. Nieczkina, Kriestjanskije wosstanija Riazina i Pugaczowa w koncepcyi M.N. Pokrowskogo, [w:] Protiw istoriczeskoj koncepcyi M.N. Pokrowskogo. Sbornik statiej, red. B. Griekow et al., cz. 1, Moskwa 1939, s. 246.

52 W. Piczeta, M.N. Pokrowskij o wojnie 1812 goda, [w:] Protiw istoriczeskoj koncepcyi..., s. 279; S. Bachruszyn, „Fieodalnyj poriadok” w ponimanii M.N. Pokrowskogo, [w:] Protiw istoriczeskoj koncepcyi..., s. 118, 126.

531937 god. Institut Krasnoj Profiessury, oprac. A.N. Artizow, W.N. Czernous, „Otieczestwiennaja istorija” 1992, nr 2, s. 123.

54 K. Radek, op. cit., s. 25, 31-34; N.I. Bucharin, op. cit., s. 10; P. Drozdow, op. cit., s. 14-17; 1937 god..., s. 123; N.L. Rubinsztejn, Russkaja istoriografija, [b.m.w.] 1941, s. 580.

55 P. Gorin, op. cit., s. 285.

56 N.I. Bucharin, op. cit., s. 15; Za prieodolenije oszybok szkoty M.N. Pokrowskogo, „Bor’ba kłassow” 1936, nr 3, s. 14; Istorik i wiremia..., s. 207; E. Jarosławskij, Kritika oszy-

Wrocławskie Studia Wschodnie 23, 2019

(C) for this edition by CNS 
Wielokrotnie powtarzano oskarżenia Pokrowskiego i jego „szkoły” o uleganie skłonności do „zamiany badania faktów ogólnymi »socjologicznymi« rozważaniami", o ignorowanie konkretności procesu dziejowego, roli jednostek osadzonych w historycznych kontekstach oraz o antyhistoryczne ujmowanie poszczególnych zjawisk w perspektywie teraźniejszości, a nie czasu i okoliczności, w których miały miejsce ${ }^{57}$. Co ciekawe, w postanowieniu KC WKP(b) z 14 listopada 1938 roku O ksztattowaniu propagandy partyjnej w związu z wydaniem ,Krótkiego kursu historii WKP(b) ” jedyna wzmianka o Pokrowskim odnosiła się do tego właśnie zagadnienia:

W nauce historycznej do ostatnich czasów antymarksistowskie wypaczenia i wulgaryzatorstwo były związane z tak zwaną szkołą Pokrowskiego, która objaśniała fakty historyczne w sposób wypaczony, wbrew materializmowi historycznemu oświetlała je z dzisiejszego punktu widzenia, a nie z punktu widzenia tych warunków, w których zachodziły wydarzenia historyczne i tym samym wypaczała rzeczywistą historię ${ }^{58}$.

Zarzuty tego rodzaju służyły nie tylko podważeniu kompetencji Pokrowskiego jako historyka-marksisty, lecz także, a może nawet przede wszystkim, zakwestionowaniu właściwego mu spojrzenia na przeszłość Rosji, co wiązało się z dokonywanym pod dyktando Stalina przewartościowaniem tej przeszłości. Zmiana polegała na przypisaniu walorów postępowości niektórym zjawiskom zdecydowanie negatywnie przedstawianym przez Pokrowskiego i jego uczniów oraz na odmiennej interpretacji i odmiennym kategoryzowaniu tych zjawisk. W związku z tym Pokrowskiemu zarzucano ignorowanie, niedocenianie bądź błędną interpretację dziejów Rusi Kijowskiej, budowy „rosyjskiego państwa narodowego", ruchów chłopskich, reform państwowych (zwłaszcza dokonanych przez Piotra I), walki z polską interwencją na początku XVII wieku i z najazdem napoleońskim w 1812 roku, powstania dekabrystów czy procesu włączania do państwa rosyjskiego poszczególnych narodów. Wysunięty właśnie przez Stalina na czoło historyków radzieckich Boris Griekow, dezawuując poglądy uczonego na dzieje Rusi Kijowskiej, sformułował znamienną uwagę:

bok i izwraszczenij ,,szkoły” Pokrowskogo, [w:] Wsiesojuznoje sowieszczanije rukowoditielej kafiedr marksizma-leninizma, Moskwa 1941, s. 92-113; Podlinno marksistskij uczebnik po istorii SRRR. Bolszaja pobieda na istoriczeskom frontie, „Istoriczeskij żurnal” 1937, nr 8, s. 6; P. Gorin, op. cit., s. 285.

${ }^{57}$ K. Radek, op. cit., s. 24; Istorik i wiremia..., s. 208. N.I. Bucharin, op. cit., s. 15; P. Drozdow, op. cit., s. 18; B. Griekow, Kijewskaja Rus' i problema proischożdienija russkogo fieodalizma u M.N. Pokrowskogo, [w:] Protiw istoriczeskoj koncepcyi..., s. 71, 76, 78, 80, 114.

${ }^{58}$ Kommunisticzeskaja partija Sowietskogo sojuza w riezolucyiach i rieszenijach sjezdow, konfieriencyj i plenumow CK, t. 2. 1925-1953, Moskwa 1953, s. 861. W późniejszych, wielotomowych edycjach postanowienie to było pomijane.

Wrocławskie Studia Wschodnie 23, 2019

(C) for this edition by CNS 
Pokrowski poszedł na rękę tym, którzy chcieli widzieć w Rosji kraj barbarzyński [...] niemający prawa zaliczać się do państw europejskich. Odrzucanie faktu istnienia państwa kijowskiego pozbawia nas broni w walce $\mathrm{z}$ wypaczeniami przeszłości narodów naszego Związku ${ }^{59}$.

Ocena stanowiska ,szkoły” Pokrowskiego w kwestii narodowej owocowała opatrywaniem jej poglądów etykietą ,lewackiego internacjonalizmu"60. Ważną rolę odgrywała tu krytyka koncepcji kapitału handlowego i jego zadania w procesie tworzenia systemu rosyjskiego samowładztwa $i$,zbierania ziem ruskich"61. To właśnie hołdowanie tego rodzaju teoriom, uznanym za wulgaryzację marksizmu, poczytywano za zasadniczy czynnik uniemożliwiający Pokrowskiemu wyjaśnienie konkretnego przebiegu rosyjskiej historii ${ }^{62}$. Oskarżyciele uczonego usilnie podkreślali, że do końca życia nie zdołał on przezwyciężyć swoich błędów i nigdy nie stał się prawdziwym marksistą ${ }^{63}$.

Na ogół nie czyniono rozróżnienia między samym Pokrowskim a jego ,szkołą", tym bardziej więc warta odnotowania jest uwaga Nikołaja Rubinsztejna:

W Rosji radzieckiej Pokrowski miał uczniów, tak zwaną historyczną szkołę Pokrowskiego. Ta szkoła rozwijała błędne, antymarksistowskie twierdzenia historycznego schematu Pokrowskiego — jedni nieświadomie, nie poddawszy ich marksistowsko-leninowskiej krytyce, inni szkodniczo, osłaniając autorytetem nauczyciela swoją antyradziecką działalność ideologiczną. Oczywiście, byłoby niesłuszne proste utożsamienie tak zwanej szkoły Pokrowskiego z samym Pokrowskim: ona nie miała za sobą tej ,przeszłości” — ani wcześniejszych zasług, ani brzemienia starych błędów; oni ponoszą odpowiedzialność za „teraźniejszość”64.

Prezentowanie w rozmaitych konfiguracjach jako błędnych koncepcji Pokrowskiego i jego ,szkoły” konsekwentnie prowadziło do wniosku, że stanowiły one przeszkodę na drodze rozwoju marksistowskiej nauki historycznej. Konkluzją było uznanie przezwyciężenia tradycji ,szkoły” Pokrowskiego za warunek ,stworzenia marksistowsko-leninowskiej historii ZSRR"65.

Bezpośrednio po zakończeniu lutowo-marcowego plenum KC WKP(b) w prasie codziennej, zwłaszcza w „Prawdzie”, oraz czasopismach specjalistycznych pojawiła się kolejna fala publikacji atakujących „szkołę” Pokrowskiego i wzywających do dalszej, jeszcze bardziej wzmożonej walki z nią i jej dziedzictwem ${ }^{66}$. Za jej kulminację można uznać dwa tomy artykułów wydane pod szyldem Instytutu Historii Akademii Nauk ZSRR. Prace

59 B. Griekow, op. cit., s. 116.

${ }^{60}$ Podlinno marksistskij uczebnik..., s. 9; A.M. Dubrowskij, op. cit., s. 261.

61 N.I. Bucharin, op. cit., s. 17-18; I. Sierogłazow, [rec.:] M.N. Pokrowskij, Russkaja istorija w samom sżatom oczerkie, Moskwa 1933, „Bor'ba kłassow” 1936, nr 4, s. 122-123.

62 K. Radek, op. cit., s. 25, 31-34.

${ }^{63}$ P. Gorin, op. cit., s. 284; I. Sierogłazow, op. cit., s. 122; 1937 god..., s. 123; N.L. Rubinsztejn, op. cit., s. 577.

64 N.L. Rubinsztejn, op. cit., s. 577.

65 Priepodawanije istorii w naszej szkole, [w:] Na froncie..., s. 25-26.

66 A.N. Artizow, Kritika..., s. 109.

Wrocławskie Studia Wschodnie 23, 2019

(C) for this edition by CNS 
nad pierwszym tomem rozpoczęły się wiosną 1937 roku, a kontynuowano je w warunkach fali represji zwanej Wielkim Terrorem, która dotknęła także bardzo wielu historyków, w tym licznych uczonych zaliczanych do „szkoły” Pokrowskiego. Tom został podpisany do druku w sierpniu 1938, a wydany w 1939 roku; tom drugi ukazał się w 1940 roku. Na obie publikacje składały się teksty krytycznie, w znacznej mierze jednostronnie, analizujące poglądy Pokrowskiego na wybrane problemy historii, a ich autorami byli badacze specjalizujący się w danej tematyce. Zasadnicze kierunki tej krytyki i generalne oceny dorobku Pokrowskiego, a w stosunkowo małym zakresie jego „szkoły”, zostały ujęte w artykułach Pankratowej (w tomie pierwszym) i Jarosławskiego (w tomie drugim).

Pankratowa powtórzyła znane już zarzuty o zastępowanie historii schematami socjologicznymi, pozbawianie narracji historycznej konkretności oraz likwidowanie historii jako nauki. Obudowywała je przykładami i szczegółami, nie cofając się przed wypaczaniem sensu wypowiedzi Pokrowskiego, a nawet przed fałszerstwami, na przykład gdy usiłowała dowieść, że już Lenin krytykował uczonego i domagał się rewizji jego stanowiska ${ }^{67}$. Badaczka twierdziła, że poglądy Pokrowskiego na historię jako naukę były sprzeczne z poglądami Marksa, Engelsa, Lenina i Stalina, były „antymarksistowskie i antyleninowskie", a tym samym antynaukowe. Jako takie przyniosły „ogromny uszczerbek rozwojowi marksistowsko-leninowskiej nauki historycznej w ZSRR, stając się glebą i bazą dla ideologicznego szkodnictwa na froncie historycznym"68. Metodologiczne podstawy poglądów Pokrowskiego widziała w materializmie ekonomicznym i idealistycznym subiektywizmie. Wynikały z nich: odrzucanie obiektywności nauki historycznej, niewłaściwe pojmowanie wzajemnych stosunków między historią a polityką, antyhistoryzm i brak dialektyki. Wyjątkowo brutalnie oceniła polityczne znaczenie koncepcji swojego niedawnego mistrza:

Antymarksistowska i antyleninowska istota historycznej metodologii Pokrowskiego i jego schematu procesu historycznego stała się szczególnie sprzyjającym gruntem dla szkodnictwa trockistowsko-bucharinowskich wrogów ludu. Na wpół trockistowskie koncepcje Pokrowskiego były wykorzystywane przez wrogów socjalizmu do walki z leninizmem, do ideologicznego szkodnictwa w ZSRR ${ }^{69}$.

Pankratowa twierdziła na przykład, że „szkoła” Pokrowskiego stała się bazą dla szkodnictwa ze strony wrogów ludu, zdemaskowanych przez organy NKWD trockistowsko-bucharinowskich najmitów faszyzmu, zdrajców, szpiegów i terrorystów, sprytnie maskujących się przy pomocy szkodliwych, antyleninowskich koncepcji historycznych

${ }^{67}$ A. Pankratowa, Razwitije istoriczeskich wzgladow M.N. Pokrowskogo, [w:] Protiw istoriczeskoj koncepcyi..., s. 5-6.

68 Ibidem, s. 68.

69 Ibidem, s. 68-69.

Wrocławskie Studia Wschodnie 23, 2019

(C) for this edition by CNS 
M.N. Pokrowskiego. Tylko niewybaczalną, idiotyczną beztroską i utratą czujności ze strony pracowników frontu historycznego można wyjaśnić fakt, że ta rozwydrzona banda wrogów leninizmu długo i bezkarnie prowadziła szkodniczą robotę w dziedzinie historii ${ }^{70}$.

Twierdziła, że „łże-historycy »ze szkoły Pokrowskiego«” pod sztandarem dyskusji historycznych ,przemycali trockistowską kontrabandę i prowadzili formalną rewizję podstaw marksizmu-leninizmu"71.

Drugi tom zbioru otwierał tekst Jemieliana Jarosławskiego stanowiący uzupełnioną wersję artykułu wydrukowanego w „Prawdzie” jeszcze w styczniu 1939 roku. Nie wnosił on jednak do krytyki Pokrowskiego wielu nowych treści. Badacz podnosił zarzuty hołdowania przez uczonego materializmowi ekonomicznemu stanowiącemu zaprzeczenie marksistowskiego pojmowania historii $^{72}$, formułował oskarżenie o wprowadzanie abstrakcyjnych schematów socjologicznych, sprzeniewierzanie się historyzmowi, ignorowanie rzeczywistego biegu walki klas, działalności wybitnych jednostek, roli mas ludowych i ich bohaterów, a także roli partii bolszewickiej jako kierowniczej siły rewolucji ${ }^{73}$. Pragnąc zdyskredytować Pokrowskiego na płaszczyźnie filozoficznej, Jarosławski dowodził powiązań poglądów historyka z teoriami Ernsta Macha i Richarda Avenariusa, co dało mu asumpt do przypisania mu idealizmu ${ }^{74}$. Powielał oskarżenia o nieuznawanie przez Pokrowskiego obiektywnego charakteru historii jako nauki i sprowadzanie jej do aktualnej polityki rzutowanej w przeszłość ${ }^{75}$. Za mającą szczególnie negatywne znaczenie Jarosławski uznał koncepcję rosyjskiego samowładztwa, która w konsekwencji jakoby miała podważać sens dokonania w Rosji rewolucji burżuazyjno-demokratycznej. Oskarżał przy tym Pokrowskiego o fałszywe przedstawienie stanowiska partii bolszewickiej i Lenina w kwestii „,przerastania” rewolucji burżuazyjno-demokratycznej w socjalistyczną ${ }^{76}$. Kolejne zarzuty Jarosławskiego odnosiły się do błędnego, szkodliwego, antymarksistowskiego przedstawienia przyczyn I wojny światowej i traktowania Rosji jako głównego winowajcy wybuchu konfliktu, przy jednoczesnym zdejmowaniu odpowiedzialności z niemieckiego i angielskiego imperializmu i niedostrzeganiu znaczenia sprzeczności między Niemcami a Anglią, która wykorzystywała carską Rosję jako „rezerwę w walce z Niemcami o światową hegemonię"77. Choć Jarosławski

${ }^{70}$ Ibidem, s. 5.

71 Ibidem, s. 6-7.

72 J. Jarosławskij, Antimarksistskije izwraszczenija i wulgaryzatorstwo tak nazywajemoj „szkoty” Pokrowskogo, [w:] Protiw antimarksistskoj koncepcji M.N. Pokrowskogo. Sbornik statiej, red. B. Griekow et al., cz. 2, Moskwa-Leningrad 1940, s. 6.

73 Ibidem, s. 6, 10.

74 Ibidem, s. 7.

75 Ibidem, s. 9.

76 Ibidem, s. 19, 21.

77 Ibidem, s. 20.

Wrocławskie Studia Wschodnie 23, 2019

(C) for this edition by CNS 
jeszcze za życia Pokrowskiego pałał do niego głęboką niechęcią, pod względem formy krytyki zachował względną powściągliwość, jeżeli porównać jego tekst choćby do wystąpienia Pankratowej.

We wszystkich ocenach dorobku Pokrowskiego i jego „szkoły” w omawianym tu okresie pojawiała się dyskwalifikacja poglądów uczonego jako niemarksistowskich. Dyskwalifikacja ta oznaczała, że dopuszczano istnienie tylko jednej wykładni marksizmu, tej mianowicie, którą aktualnie prezentował bądź akceptował Stalin. Dla oceny jakiegoś poglądu rozstrzygające znaczenie zyskiwała jego zgodność z odpowiednio interpretowanymi wypowiedziami klasyków marksizmu, przede wszystkim Lenina. Status jedynego właściwego interpretatora Lenina zawłaszczył sobie Stalin, co koniec końców oznaczało, że to on stawał się „ostatnią instancją” kwalifikującą dane poglądy jako marksistowskie bądź antymarksistowskie.

Kwalifikacja poglądów Pokrowskiego i jego uczniów jako niemarksistowskich miała wszakże jeszcze inny sens. Odrzucenie ich z tego właśnie powodu pozwalało tym skuteczniej głosić ich błędność w odniesieniu do konkretnych zjawisk z przeszłości Rosji: budowy i roli państwa, znaczenia scentralizowanej władzy państwowej jako czynnika postępu czy charakteru aneksjonistycznej polityki caratu. W tej ostatniej kwestii po latach Nieczkina przyznała, że walce ze „szkołą” Pokrowskiego służyła formuła „mniejszego zła” w zupełnie odmiennym świetle sytuująca zagarnięcie Ukrainy, Zakaukazia i Azji Środkowej ${ }^{78}$. Z punktu widzenia dokonywanej przez Stalina reinterpretacji przeszłości Rosji teksty zawarte we wspomnianej dwutomowej publikacji Instytutu Historii Akademii Nauk ZSRR, analizujące błędy „szkoły” Pokrowskiego w zakresie konkretnych zagadnień tej historii, miały wartość trudną do przecenienia. Znamienne było, że poglądy określane jako antymarksistowskie, zastępowane były mającymi z marksizmem znacznie mniej wspólnego, choć z sankcji najwyższego autorytetu Stalina ogłaszane były jako ,prawowierne”.

Kampania przeciwko Pokrowskiemu i jego „szkole” doprowadziła do wyeliminowania znacznej części historyków o marksistowskiej orientacji metodologicznej i ideologicznej, zwłaszcza ze środowiska Instytutu Czerwonej Profesury. Będąc współtwórcami stalinowskiej polityki w dziedzinie nauki, stali się ofiarami tej polityki, gdy przywództwo zadecydowało o zmianie linii. Ich miejsce zajęli uczeni wywodzący się ze „starej szkoły” przedrewolucyjnej, między innymi Siergiej Bachruszyn, Jewgienij Tarle, Boris Griekow, Władimir Piczeta i Aleksiej Jakowlew. Dokonawszy reorientacji ideologicznej, a zarazem dysponując rozległą wiedzą i dobrym warsztatem naukowym, okazali się lepiej przygotowani do realizacji zadań wyznaczanych przez

78 M. Nieczkina, $K$ woprosu o formule ,naimienszeje zło” (Pis'mo w riedakcyju), „Woprosy istorii" 1951, nr 4, s. 44.

Wrocławskie Studia Wschodnie 23, 2019

(C) for this edition by CNS 
Stalina niż wielu historyków-marksistów, których poglądy ukształtowały się w latach dwudziestych ${ }^{79}$. W większości byli to uczeni represjonowani na początku lat trzydziestych w związku z tak zwaną sprawą akademicką, przywróceni „do łask” przez Stalina i gotowi poprzeć bardziej „narodowo” i ,imperialistycznie” zorientowaną politykę historyczną.

\section{Bibliografia}

1937 god. Institut Krasnoj Profiessury, oprac. A.N. Artizow, W.N. Czernous, „Otieczestwiennaja istorija" 1992, nr 2, s. 119-146.

Akadiemik P.O. Gorin. Dokumienty i matieriały, red. N.W. Tokariew, Minsk 2011.

Aleksiejewa G.D., Istorija, Idieołogija. Politika. (20-30-je gg), [w:] Istoriczeskaja nauka Rossii w XX wiekie, red. G.D. Aleksiejewa, Moskwa 1997, s. 79-166.

Artizow A.N., Kritika M.N. Pokrowskogo i jego szkoly (K istorii woprosa), „Istorija SSSR” 1991, nr 1, s. 102-120.

Artizow A.N., Nikołaj Nikołajewicz Wanag (1899-1937 gg.), „Otieczestwiennaja istorija” 1992, nr 6, s. 95-109.

Asher H., The rise, fall, and resurrection of M.N. Pokrovsky, „The Russian Review” 1972, nr 1, s. 49-63.

Barber J., Soviet Historians in Crisis 1928-1932, London-Basingstoke 1981.

Brandenberger D., Politics projected into the past: What precipitated the 1936 campaign against M.N. Pokrovsky?, [w:] Reinterpreting Revolutionary Russia: Essays in Honour of James D. White, red. I.D. Thatcher, London 2006, s. 202-214.

Brandenberger D., Who killed Pokrovskii? (the second time): The prelude to the denunciation of the father of soviet Marxist historiography, January 1936, „Revolutionary Russia” 1998, nr 1, s. 67-73.

Brandenberger D.L., Dubrovsky A.M., "The People Need a Tsar”: The Emergence of National Bolshevism as Stalinist Ideology 1931-1941, „Europe-Asia Studies” 1998, nr 5, s. 873-892.

Bucharin N.I., Nużna li nam marksistskaja istoriczeskaja nauka? (Oniekotorych suszczestwienno ważnych, no nie sostojatielnych wzgliadach t. M.N. Pokrowskogo), „Bor'ba kłassow” 1936, nr 2, s. 10-19.

Ciesielski S., Poczatki stalinowskiego zwrotu wobec historii (1930-1931), „Wrocławskie Studia Wschodnie" 21, 2017, s. 89-110.

Ciesielski S., Rewolucja Stalina, Łomianki 2017.

Czernobajew A.A., ,, Profiessor s pikoj” ili tri żyzni istorika M.N. Pokrowskogo, Moskwa 1992.

Dniewnik istorika S.A. Piontowskogo (1927-1934), red. A.L. Litwin, Kazań 2009.

Drozdow P., Rieszenije partii i prawitielstwa ob uczebnikach po istorii i zadaczi sowietskich istorikow, „Istorik-marksist” 1936, nr 1 (53), s. 9-22.

Dubrowskij A.M., Istorik $i$ włast'. Istoriczeskaja nauka w SSSR $i$ koncepcyia istorii fieodalnoj Rossii w kontiekstie politiki i idieołogii (1930-1950-je gg), Briansk 2005.

Enteen G.M., The Soviet Scholar Bureaucrat: M.N. Pokrovskii and the Society of Marxist Historians, Pensylvania 1978.

Goworkow A.A., M.N. Pokrowskij o priedmietie istoriczeskoj nauki, Tomsk 1976.

79 Zob. W.W. Tichonow, op. cit., s. 82.

Wrocławskie Studia Wschodnie 23, 2019

(C) for this edition by CNS 
I.W. Stalin — „O statje Engelsa »Wniesznaja politika russkogo carizma«”- i idieołogiczeskaja podgotowka k mirowoj wojnie, red. M.W. Zielenow, „Woprosy istorii” 2002, nr 7, s. 3-40.

I.W. Stalin. Istoriczeskaja idieołogija w SSSR w 1920-1950-je gody: Pieriepiska s istorikami, stati i zamietki po istorii, stienogrammy wystuplenij. Sbornik dokumientow i matieriałow, red. M.W. Zielenow, t. 1, Sankt-Pietierburg 2006.

Istorik i wriemia. 20-50-je gody XX wieka. A.M. Pankratowa, red. J.S. Kukuszkin, Moskwa 2000.

Kak Stalin kritikowat i riedaktirowat konspekty szkolnych uczebnikow po istorii (1934-1936 gody), oprac. M.W. Zielenow, „Woprosy istorii” 2004, nr 6, s. 3-30.

Kommunisticzeskaja partija Sowietskogo sojuza $w$ riezolucyiach $i$ rieszenijach sjezdow, konfieriencyj i plenumow CK, t. 2. 1925-1953, Moskwa 1953.

Łarina A.M., Niezabywajemoje, Moskwa 1989.

Łuckij J.A., Razwitije istoriczeskoj koncepcyi M.N. Pokrowskogo, [w:] Istorija i istoriki. Istoriografija istorii SSSR. Sbornik statiej, red. M.N. Nieczkina, Moskwa 1965, s. 334-370.

Na frontie istoriczeskoj nauki, Moskwa 1936.

Nieczkina M., K woprosu o formule „naimienszeje zło” (Pis'mo w riedakcyju), „Woprosy istorii" 1951, nr 4, s. 44-48.

Nieczkina M., Wopros o Pokrowskom w postanowlenijach partii i prawitielstwa 1934-1938 gg. o priepodawanii istorii i istoriczeskoj naukie ( $K$ istocznikowiedczeskoj storonie tiemy), „Istoriczeskije zapiski” 118, 1990, s. 232-246.

„Nużen bolszewistskij Iłowajskij”: Iz stienogrammy sowieszczanija narkoma proswieszczenija RSFSR A.S. Bubnowa s istorikami o stabilnom uczebnikie, red. S.J. Zaczejko, T.J. Krasowickaja, http:/www.alexanderyakovlev.org/almanah/inside/almanah-doc/1022578 (dostęp: 17.03.2017).

Pankratowa A., M.N. Pokrowskij - bolszewistskij istorik, „Bor'ba kłassow” 1932, nr 4, s. 20-35.

Pankratowa A., Za bolszewistskoje priepodawanije istorii, „Bor’ba kłassow” 1935, nr 1-2, s. 19-36.

Perrie M., The Cult of Ivan the Terrible in Stalin's Russia, Basingstoke 2001.

Podlinno marksistskij uczebnik po istorii SRRR. Bolszaja pobieda na istoriczeskom frontie, „Istoriczeskij żurnał” 1937, nr 8, s. 6-12.

Politbiuro CK RKP(b)-WKP(b). Powiestki dnia zasiedanij 1919-1952. Katałog, red. G.M. Adibiekow, K.M. Anderson, L.A. Rogowaja, t. 2, Moskwa 2001.

Protiw antimarksistskoj koncepcji M.N. Pokrowskogo. Sbornik statiej, red. B. Griekow et al., cz. 2, Moskwa-Leningrad 1940.

Protiw istoriczeskoj koncepcyi M.N. Pokrowskogo. Sbornik statiej, red. B. Griekow et al., cz. 1, Moskwa 1939.

Radek K., Niedostatki istoriczeskogo fronta i oszybki szkoty Pokrowskogo, „Bor'ba kłassow” 1936, nr 3, s. 24-38.

Rubinsztejn N.L., Russkaja istoriografija, [b.m.w.] 1941.

Sokołow O.D., M.N. Pokrowskij i sowietskaja istoriczeskaja nauka, Moskwa 1970.

Sokołow W.J., Istorija i politika (K woprosu o sodierżanii i charaktierie diskussij sowietskich istorikow 1920-ch-naczała 1930-ch gg.), Tomsk 1990.

Stalin I.W., Soczinienija, t. 7, Moskwa 1952.

Tichonow W.W., Istoriki, idieołogija, włast'w Rossii XX wieka. Oczerki, Moskwa 2014.

Wsiesojuznoje sowieszczanije rukowoditielej kafiedr marksizma-leninizma, Moskwa 1941.

Za prieodolenije oszybok szkoty M.N. Pokrowskogo, „Bor'ba kłassow” 1936, nr 3, s. 13-16.

Wrocławskie Studia Wschodnie 23, 2019

(C) for this edition by CNS 


\title{
Сталин против Покровского. Из истории сталинской «исторической политики»
}

\author{
Резюме
}

Михаил Покровский в двадцатых годах и в первой половине тридцатых годов XX века считался признанным лидером марксистской историографии в СССР. Начатая Сталиным переоценка многих явлений в истории России, связанная со стремлением к интеграции советского общества на основе особого патриотизма и чувства державности привела к оспариванию и отрицанию прежней исторической политики, символом которой был Покровский. Неудача попытки создания учениками Покровского школьных учебников стало для Сталина импульсом для начала кампании, направленной на учёного и его «школу». Во время её взгляды Покровского были признаны антимарксистскими и антиленинскими. Его обвиняли в том, что, исповедуя экономический материализм и когнитивный субъективизм, не понимая диалектики, он проповедовал вульгарный марксизм, трактовал историю как политику возврата в прошлое и оспаривал её объективизм как науки, а как следствие этого стоял на позиции ликвидаторского подхода к истории. Покровскому приписывали игнорирование конкретности исторического процесса, роли выдающихся личностей, антиисторическое понимание отдельных явлений с перспективы современности, а не обстоятельств, при которых они имели место. Важную роль играла критика торгового капитала и его исторической роли. Подвергнуты сомнению были ключевые элементы свойственной Покровскому картины прошлого России. Покровского обвиняли в игнорировании, недооценке или ошибочной интерпретации истории Киевской Руси, строительства «российского народного государства», крестьянских движений, государственных реформ, борьбы с польской интервенцией в начале XVII века и с нашествием Наполеона в 1812 году, восстания декабристов, процесса включения в Российское государство других народов.

\section{Stalin against Pokrovsky: On the history of Stalinist "historical policy"}

\author{
Summary
}

In the 1920s and the first half of the 1930s Mikhail Pokrovsky was regarded as a leading Marxist historiographer in the USSR. A revision, initiated by Stalin, of views on many phenomena from Russia's history, connected with a desire to consolidate Soviet society on the basis of a redefined patriotism and feeling of being part of a superpower, led to a questioning and rejection of the historical policy which Pokrovsky symbolised. The failure to prepare new school textbooks by Pokrovsky's pupils prompted Stalin to launch a campaign against the scholar and his "school." Pokrovsky's views were pronounced anti-Marxist and anti-Leninist. As a man allegedly kowtowing to economic materialism and cognitive subjectivism, and not understanding dialectics, Pokrovsky was accused of vulgarising Marxism, treating history as a policy of projecting into the past and questioning its objectivism as a science, and, consequently, of representing an approach 
to it that was that of a liquidator. Pokrovsky was said to be ignoring the concreteness of the historical process, the role of outstanding individuals, to be following an ahistorical approach to various phenomena from the perspective of the present and not of the circumstances in which they had taken place. An important role was played by criticism of the concept of commercial capital and its historical role. Key elements of Pokrovsky's picture of Russia's past were questioned. Pokrovsky was accused of ignoring, failing to appreciate or misinterpreting the history of Kievan Rus', of the building of the "Russian nation state," peasant movements, state reforms, fight against the Polish intervention in the early 17th century and the Napoleonic invasion in 1812, the Decembrist Uprising, and the process of incorporating various nations into the Russian state. 